\title{
Vpliv kakovosti prostorskih podatkov na učinkovitost sistema obdavčenja nepremičnin: primer nadomestila za uporabo stavbnega zemljišča
}

Prostorski podatki niso neposredno povezani le s prostorskim načrtovanjem, temveč z urejanjem prostora na splošno in $s$ tem tudi s sistemom obdavčenja nepremičnin. Kakovost prostorskih podatkov vpliva na učinkovitost sistema obdavčenja nepremičnin, njegovo izdatnost, pravičnost in racionalnost. V članku je opredeljen metodološki pristop $\mathrm{k}$ analizi kakovosti prostorskih podatkovnih nizov zbirk podatkov, ki jih občine upravljajo za odmero nadomestila za uporabo stavbnega zemljišča. Za analizo kakovosti podatkov sta za raziskavo opredeljena in uporabljena prilagojena Jaccardov in Czekanowskijev koeficient, ki sta uporabna, kadar so razlike med primerjanima podatkoma manjše od $5 \%$. S tema koeficientoma se ugotovi raven ujemanja površin stavb in nezazidanega stavbnega zemljišča iz občinskih zbirk podatkov za odmero nadomestila za uporabo stavbnega zemljišča in iz registra nepremičnin. Na podlagi analize popolnosti, logične usklajenosti in tematske natančnosti občinskih zbirk podatkov za odmero nadomestila za uporabo stavbnega zemljišča je izvedena posodobitev občinskih zbirk podatkov. Analizirane so spremembe v občinski zbirki podatkov po posodobitvi, in sicer glede števila zavezancev za plačilo nadomestila za uporabo stavbnega zemljišča in odmere nadomestila za uporabo stavbnega zemljišča. Rezultati prve tovrstne raziskave so dobljeni na manjšem vzorcu, vendar je metodologija uporabna tudi za izvedbo analize na večjem vzorcu oziroma v vseh občinah v Sloveniji. Poleg tega je lahko v podporo strokovnjakom na občinah, prostorskim načrtovalcem in odločevalcem na področju davčne politike.

Ključne besede: urejanje prostora, prostorsko načrtovanje, kakovost prostorskih podatkov, obdavčitev nepremičnin 


\section{Uvod}

Prostorski podatki opredeljujejo stvarni svet $\mathrm{z}$ različnih vidikov, pojave v prostoru neposredno ali posredno povezujejo $\mathrm{z}$ lokacijo in so od nekdaj temelj določanja lastnosti nepremičnin (Yomralioglu idr., 2007; Ažman, 2011). Prostorski podatki so neposredno povezani s prostorskim načrtovanjem in urejanjem prostora na splošno (Zakrajšek, 1999). Mangioni (2012), Mantey in Tagoe (2012) ter Çağdaş (2013) poudarjajo pomen uporabe prostorskih podatkov in sodobne GIS-tehnologije pri vzpostavitvi in upravljanju sistema obdavčitve nepremičnin kot dela sistema urejanja prostora. Poudarjajo, da uporaba kakovostnih prostorskih podatkov pomembno vpliva na učinkovitost sistema, njegovo izdatnost, pravičnost in racionalnost. Droj in Droj (2010) izpostavljata pomen prostorskih podatkov za dobro upravljanje in kakovostno odločanje na področju obdavčitve nepremičnin. Robbins (2014) potrjuje pozitiven vpliv uporabe prostorskih podatkov, GIS-tehnologije, prostorskih znanj ter ustrezne dostopnosti in kartografske upodobitve podatkov o nepremičninah v procesu upravljanja prostora, prostorskega načrtovanja in obdavčevanja nepremičnin (Zavodnik Lamovšek idr., 2012). Maher idr. (2005) in Robbins (2014) pri tem izpostavljajo vlogo GIS-tehnologije in (horizontalno in vertikalno) povezovanje zbirk prostorskih podatkov na lokalni in nacionalni ravni. Jankovič Grobelšek in Gajš̌k (2014) ob tem poudarjata, da mora učinkovita nepremičninska zakonodaja temeljiti na celovito urejenih podatkih prostorskega informacijskega sistema.

Obdavčitev nepremičnin je povezana z zahtevo po visoki kakovosti podatkov o nepremičninah. V Sloveniji in številnih državah sveta trenutno potekajo reforme sistemov obdavčitve nepremičnin. Uspešnost izvedbe teh reform je odvisna tudi od razpoložljivosti zbirk prostorskih in drugih podatkov o nepremičninah ter njihove kakovosti. Bolj ko je sistem evidentiranja nepremičnin točen in popoln, višja je raven pravne varnosti pravnih razmerij in večje je zaupanje $\mathrm{v}$ sistem, $s$ tem pa tudi njegova uporabnost (Starček, 2017). Pri obravnavi prostorskih pojavov gre po navadi za kompleksen in medsektorsko prepleten sistem prostorskih podatkov, pri čemer je kakovost podatkov pomemben dejavnik kakovosti in učinkovitosti sistema, ki uporablja te podatke. Zato je treba, kot poudarja van der Molen (2002), posebno pozornost nameniti zagotavljanju kakovostnih in zaupanja vrednih prostorskih podatkov o nepremičninah, ki so med seboj povezani in usklajeni, čeprav so vodeni v več zbirkah podatkov.

Raziskava v tem članku je osredotočena na analizo vpliva kakovosti prostorskih podatkov na sistem obdavčenja nepremičnin v Sloveniji. Tovrstni sistemi se v državah po svetu stalno spreminjajo (Slack in Bird, 2014). Uspešnost reform in poznejša učinkovitost sistema obdavčitve nepremičnin pa sta odvisni tudi od kakovosti zbirk podatkov o nepremičninah. Podobno kot $\mathrm{v}$ številnih državah vzhodne in srednje Evrope tudi v Sloveniji že več kot dve desetletji poteka prehod iz sistema obdavčitve nepremičnin, ki temelji na površini nepremičnine (area-based), v nov sistem, ki temelji na tržni vrednosti nepremičnin (ad-valorem). V Sloveniji je zdajšnji sistem obdavčitve nepremičnin zastarel, neenoten, nepregleden in neprilagojen novim gospodarskim razmeram (Vlada RS, 2013).Zato so bile v minulih dveh desetletjih izvedene številne dejavnosti za oblikovanje sodobnega in na tržnih razmerah temelječega sistema obdavčitve nepremičnin. Prvi poskus za uvedbo novega načina obdavčitve nepremičnin je bil narejen leta $2013 \mathrm{~s}$ sprejetjem Zakona o davku na nepremičnine (2013), ta zakon pa je Ustavno sodišče RS (2014) v celoti razveljavilo, in sicer predvsem zaradi neskladnosti z Ustavo RS. V svoji odločitvi je med drugim izpostavilo tudi zahtevo po izboljšanju kakovosti podatkov o nepremičninah.

Reforma sistema obdavčenja nepremičnin v Sloveniji se torej izvaja, zato lahko vpliv prostorskih podatkov na učinkovitost sistema obdavčenja nepremičnin analiziramo le na podlagi podatkov, ki jih občine upravljajo za odmero nadomestila za uporabo stavbnega zemljišča (v nadaljevanju: NUSZ). NUSZ je dajatev, ki poleg davka na premoženje občanov in pristojbine za vzdrževanje gozdnih cest skupaj tvori davek na nepremičnine, $\mathrm{v}$ veljavi pa je že od leta 1984. NUSZ se odmerja v vseh občinah v Sloveniji. Prihodki od NUSZ so od njegove uveljavitve eden najpomembneješih in najstabilnejših javnofinančnih virov občin. Občine s prihodki od NUSZ zagotavljajo ustrezno komunalno opremljenost stavbnih zemljišč ter gospodarski in družbeni razvoj. Po podatkih Ministrstva za finance (2017) prihodki od NUSZ znašajo v povprečju skoraj $90 \%$ vseh prihodkov od davkov od premoženja občin oziroma $15 \%$ vseh davčnih prihodkov občin. Pravne osebe zajemajo $4 \%$ vseh zavezancev za plačilo NUSZ. Pri tem odmera NUSZ za poslovne namene zajema $70,5 \%$ celotne višine odmere.

Cilj raziskave je ugotoviti, ali izboljšanje kakovosti občinskih zbirk podatkov za odmero NUSZ s podatki registra nepremičnin in zbirnega katastra gospodarske javne infrastrukture prispeva $\mathrm{k}$ zvišanju odmere NUSZ. V raziskavi smo izhajali iz domneve (hipoteza H1), da je odsotnost zapisov o stavbah in nezazidanih stavbnih zemljiščih v občinskih zbirkah podatkov za odmero NUSZ v povprečju večja kot $10 \%$ glede na stanje v registru nepremičnin. Predpostavili smo še (hipoteza H2), da je ujemanje podatkov o površinah stavb in nezazidanem stavbnem zemljišču med občinskimi zbirkami podatkov za odmero NUSZ in registrom nepremičnin razmeroma šibko, kar pomeni, da sta vrednosti prilagojenih Jaccardovega in Czekanowskijevega koeficienta manjši od 0,33 . Predvidevali smo tudi (hipoteza $\mathrm{H} 3$ ), da posodobitev podatkovnih nizov v občinskih 
zbirkah podatkov s podatki iz registra nepremičnin vpliva na povečanje števila zavezancev in višino odmere NUSZ.

\section{Kakovost prostorskih podatkov in zadevne raziskave}

Prostorski podatki so raznovrstni tako po položajni in časovni kakovosti kot po kakovosti pomenske opredeljenosti pojmov. Opredelitev kakovosti prostorskih podatkov je odvisna od področja obravnave, namena, zahtev in pričakovanj uporabnikov in drugih subjektivnih dejavnikov. Na splošno izraža kakovost prostorskih podatkov celotnost lastnosti zbirke podatkov glede na njeno sposobnost, da ustreza izraženemu ali vsebovanemu nizu zahtev. Je torej razlika med podatki in stvarnim svetom, ki ga podatki ponazarjajo. Večja je ta razlika, slabša je kakovost podatkov, $s$ tem sta manjši tudi uporabna in siceršnja vrednost teh podatkov (Triglav, 2012).

Kakovost podatkov opredeljujejo tudi namen, izvor in uporaba kot opisni in kvantitativni elementi (Morrison, 1995; Veregin, 1999; Šumrada, 2005; Ivánová, 2007). Slovenski standard SIST EN ISO 19157:2015 Geografske informacije - Kakovost podatkov opredeljuje poenoteni kakovostni model za prostorske podatke in osnovno metodologijo za določanje njihove kakovosti. Kakovost podatkov je v skladu z načeli kakovosti omenjenega standarda razlika med podatkovno zbirko in med stvarnim ali hipotetičnim svetom, t. i. prostorom obravnave, določenim s podatkovnimi specifikacijami. Osnovni elementi kakovosti, kot jih opredeljuje standard, so položajna točnost, tematska natančnost, logična usklajenost, časovna kakovost, popolnost in uporabnost.

Izvedene so bile številne raziskave, povezane s področjem prostorskih podatkov o nepremičninah za njihovo vrednotenje in obdavčitev nepremičnin (Kokkonen, 2006; Tomić, 2010). Barańska (2004) je raziskovala elemente kakovosti zbirk podatkov in stohastične modele napovedovanja tržnih vrednosti nepremičnin. Barvika idr. (2013) so raziskovali povezovanje zbirk podatkov o nepremičninah s podatki množičnega vrednotenja nepremičnin za obdavčitev nepremičnin. Mangioni (2012) je raziskoval vpliv informiranosti in dostopnosti podatkov o nepremičninah na načela dobrega davčnega sistema obdavčitve nepremičnin. V številnih raziskavah je bil dan poudarek razvoju metod presoje kakovosti prostorskih podatkov (Pipino idr., 2002; McKay, 2003; Cerovski, 2010; Xia, 2012). Razviti so bili številni avtomatizirani metode in orodja za podporo presoje kakovosti podatkov (Podobnikar, 2001; Li idr., 2012) ali le izbranega elementa kakovosti (Goodchild in Hunter, 1997; Ariza-López in Mozas-Calvache, 2012; Hast, 2014; Hashemi in Abbaspour, 2015). Maggio (2012) izpostavlja pomen izboljšanja kakovosti podatkov o nepremičninah v Italiji pri odmeri občinskega davka na nepremičnine in davka na odlaganje odpadkov, pri čemer se drugonavedeni odmerja tudi glede na površino nepremičnine. Na podlagi podatkov, ki so jih predložili lastniki zemljišč in stavb, podatkov iz drugih uradnih zbirk in ortofoto posnetkov so izboljšali kakovost grafičnih in opisnih podatkov katastra stavb in zemljišč. Posledica izboljšanja popolnosti zbirk podatkov o nepremičninah sta bila povečanje prihodkov od omenjenih davkov in več zaznanih nezakonitih gradenj.

Caeiro idr. (2016) poudarjajo učinek izboljšanja kakovosti podatkov katastra nepremičnin na Portugalskem na vrednotenje nepremičnin in odmero davka na nepremičnine. Na območju Lizbone so z aktivnim vključevanjem latnikov nepremičnin, zajemom podatkov o lastništvu nepremičnin in terenskimi geodetskimi izmerami izboljšali popolnost, tematsko natančnost, logično usklajenost in položajno točnost podatkov o nepremičninah. Izboljšanje kakovosti podatkov o nepremičninah je pomembno vplivalo tudi na urejenost lastniških razmerij in uporabnost podatkov tudi za druge namene. Popolnost zbirk podatkov o zemljiščih in stavbah, ki pomembno vpliva na prihodke od obdavčitve nepremičnin, je v državah Evropske unije različna. Po podatkih Organizacije združenih narodov (Združeni narodi, 2014) je v državah Evropske unije evidentiranih več kot $80 \%$ vseh zemljišč. Največji delež je v srednjeevropskih in skandinavskih državah. V Armeniji je večina neevidentiranih zemljišč v lasti države. Na Malti ugotovitve kažejo, da je delež evidentiranih zemljišč večji na urbanih območjih. $V$ Španiji sta približno $2 \%$ neevidentiranih zemljišč, ki so večinoma na podeželju.

Slovenija je v letih po osamosvojitvi vložila precejšnja sredstva v razvoj in vzpostavitev različnih zbirk podatkov o prostoru. Kot navaja Petrovič (2006), so se te vzpostavljale hitro, a pogosto brez zadostnega in ustreznega zagotavljanja kakovosti. V Sloveniji so izvedene številne študije kakovosti posameznih zbirk prostorskih podatkov. Geodetski inštitut Slovenije (2003) je ugotovil, da je približno četrtina podatkov zemljiškega katastra slabe ali zelo slabe kakovosti, predvsem na ruralnih območjih in območjih manj intenzivne rabe. Ferlan (2005), Čeh idr. (2011), Ferlan idr. (2011) in Bohak (2016) so poudarili, da je zbirka digitalnih katastrskih načrtov neusklajena, in opozorili na različne položajne točnosti. Pogost predmet raziskav sta tudi kataster stavb (Geodetski inštitut Slovenije, 2015; Triglav Čekada idr., 2016) in register nepremičnin (Lisec idr., 2015; Mitrović, 2015; Požun, 2015; Starček, 2017). Smodiš (2011) je poudaril, da je kakovost določanja posplošene tržne vrednosti nepremičnin odvisna tudi od kakovosti podatkov o nepremičninah v registru nepremičnin. Mitrović (2015) je opozoril na nizko raven kakovosti podatkov, ki jih v evidenco trga nepremičnin predložijo zavezanci. 
Kobetič (2014) je glede prostorskih podatkov ugotovil, da podatkov, potrebnih za odmero NUSZ, ni, podatki niso vodeni v ustrezni obliki ali so podatki slabo vzdrževani. Grilc (2017) in Ziherl (2017) sta ugotovila, da je posodobitev zbirke podatkov mestne občine Kranj s podatki iz registra nepremičnin vplivala med drugim na povečanje števila zavezancev in posledično prihodkov od NUSZ. Grilc (2017) za učinkovito izboljšanje kakovosti podatkov izpostavlja tudi pomen javne razgrnitve podatkov o nepremičninah ter sodelovanje lastnikov nepremičnin in strokovnjakov s področja prostorskih podatkov. Gerčer (2017) je posebej opozoril na odstopanja med podatki o površini stavbnih zemljišč $\mathrm{v}$ občinskih zbirkah podatkov za odmero NUSZ in podatki iz registra nepremičnin. Mivšek in Radovanova (2017) sta izpostavila, da raznovrstna kakovost podatkov vpliva na nepravilnosti pri odmeri NUSZ. Urankarjeva (2016) je menila, da je zaradi nepopolnosti občinskih zbirk podatkov za od $20 \%$ do $30 \%$ manjši prihodek od NUSZ. Finančna uprava RS (2014) navaja, da zavezanci za plačilo NUSZ občin ne obveščajo sproti o spremembah, ki vplivajo na odmero NUSZ. Režek idr. (2015) ob tem izpostavljajo, da lahko množica ponudnikov zbirk prostorskih podatkov in sodobne tehnologije za njihovo pridobivanje povzročijo nekritičnost pri uporabi prostorskih podatkov. Zato so lahko rešitve, predlogi in ukrepi, ki temeljijo na takih podatkih, dvomljive kakovosti. Vse navedeno kaže na pomembnost zagotavljanja kakovostnih prostorskih podatkov.

\section{Zbirke podatkov za obdavčitev nepremičnin v Sloveniji}

Predmet obdavčitve pri NUSZ sta zazidano in nezazidano stavbno zemljišče. Med zazidana stavbna zemljišča se uvrš̌cajo površine za stanovanjski in poslovni namen. Davčno osnovo tvori površina nezazidanega stavbnega zemljišča, stanovanjska površina oziroma poslovna površina. Občine površine zemljišča, stanovanj in stavb za poslovni namen določajo na različne načine. Z odlokom o NUSZ določijo merila in število točk glede na lastnosti stavbnega zemljišča in njegovih prednosti ali slabosti. Zakon o stavbnih zemljiščih $(1984 ; 1997)$ ni določal vseh meril za predpisovanje NUSZ, zaradi česar lahko občine merila in število točk pogosto določajo arbitrarno. Pri tem imajo vzpostavljene lastne zbirke podatkov za odmero NUSZ, ki se po večini, kot navaja Kobetič (2014), ne povezujejo z referenčnimi zbirkami podatkov (zemljiški kataster, kataster stavb in register nepremičnin). To, kot poudarjajo Grote idr. (2015), pomembno vpliva na neracionalnost in nepreglednost sistema obdavčitve nepremičnin v Sloveniji. Šele Zakon o graditvi objektov (2004) je določil obveznost uporabe uradnih zbirk podatkov (zemljiški kataster, kataster stavb in register nepremičnin) pri upravljanju sistema NUSZ, kar pa vse občine ne upoštevajo.
Podatki, potrebni za upravljanje sistema NUSZ, se med občinami razlikujejo in so odvisni od določil odloka oziroma meril. Občine med merili upoštevajo predvsem lego v prostoru, opremljenost $s$ komunalno infrastrukturo, funkcionalno ugodnost lokacije stavbnega zemljišča, namensko rabo po prostorsko izvedbenih aktih, gostoto javnih funkcij in poslovnih dejavnosti ter stalne čezmerne motnje pri uporabi stavbnega zemljišča. Nekatere občine upoštevajo še konfiguracijo terena, zasedenost stavb in zemljišč, število lastnih parkirnih mest, dostopnost z javnimi prometnimi sredstvi, motnje pri uporabi stavbnega zemljišča, zapuščenost in dotrajanost objekta idr. Kataster stavb, zemljiški kataster in register nepremičnin ne vsebujejo vseh podatkov, ki jih občine potrebujejo za določitev števila točk in določitev davčnega bremena z NUSZ. Občine zato ob podatkih iz referenčnih zbirk prostorskih podatkov pridobivajo podatke še iz grafičnega dela zemljiškega katastra, digitalnih podlag veljavnih prostorskih sestavin dolgoročnega in srednjeročnega družbenega plana ter iz drugih virov.

Podatki o nepremičninah se v Sloveniji vodijo v več referenčnih zbirkah podatkov, ki se uporabljajo za obdavčitev nepremičnin, in sicer v zemljiškem katastru, katastru stavb, zemljǐ̌ki knjigi, zbirnem katastru gospodarske javne infrastrukture, registru nepremičnin, zbirki vrednotenja nepremičnin, evidenci trga nepremičnin, registru prostorskih enot in zbirki topografskih in kartografskih podatkov. V katastrih so podatki o predmetu pravic in pravnih razmerij, ki so evidentirani v zemljiški knjigi. Za podatke o nepremičninah kot o predmetu pravic je kataster izvorna evidenca. Register nepremičnin je javna evidenca o vseh nepremičninah, ki v evidenčnem smislu vzpostavlja nepremičnino. Določen je kot odprt sistem, ki omogoča, da uporabniki s svojimi predpisi v skladu s svojimi nameni dopolnjujejo njegovo večnamenskost tako, da določijo dodatne podatke, ki se vodijo o nepremičninah (Geodetska uprava RS, 2013). Register nepremičnin kot podatkovna zbirka že sam po sebi ni popoln zaradi nepopolnosti evidenc, iz katerih prevzema podatke, in je omejene kakovosti, $\mathrm{k}$ čemur sta največ prispevala neustrezno izvedeni popis nepremičnin in predpisani način spreminjanja podatkov. Kljub temu menimo, da je kakovostnejša podatkovna zbirka kot podatkovna zbirka za odmero NUSZ. To sledi tudi iz sistemskih priporočil za izboljšanje sistema NUSZ (Ministrstvo za okolje in prostor idr., 2016).

\section{Empirična raziskava kakovosti občinske zbirke podatkov za odmero NUSZ}

\subsection{Metodologija}

V raziskavi smo podatkovne nize o stavbah za stanovanjski in poslovni namen in nezazidanih stavbnih zemljiščih, ki jih ob- 
čine vodijo v zbirkah podatkov za odmero NUSZ, primerjali s podatkovnimi nizi registra nepremičnin kot referenčne zbirke podatkov. Najprej smo analizirali odloke za odmero NUSZ v izbranih občinah. Pridobili smo podatke za devet občin, ki so pristopile $\mathrm{k}$ projektu posodobitve zbirke podatkov za odmero NUSZ in od katerih smo lahko pridobili tudi ustrezne podatke za izvedbo navedene analize. Analizirali smo vrsto in vire podatkov, ki jih občine uporabljajo za odmero NUSZ. Pri analizi kakovosti tovrstnih podatkovnih nizov smo se osredotočili na tri osnovne elemente kakovosti, kot jih opredeljuje standard ISO 19157:2015, in sicer popolnost, tematsko natančnost in logično usklajenost občinskih zbirk podatkov.

Za vse obravnavane občine smo potem izračunali ujemanje podatkov o številu delov stavbe in ujemanje podatkov o površini stavbe v občinskih zbirkah podatkov za odmero NUSZ s podatki iz registra nepremičnin. Znanih je več metod določanja podobnosti med množicami (Romesburg, 2004; Albatineh in Niewiadomska-Bugaj, 2011; Liu idr., 2014; Aamir in Bhusry, 2015). V raziskavi smo za izračun ujemanja podatkov o številu delov stavbe med obravnavanima podatkovnima zbirkama uporabili Jaccardov koeficient, ki se pogosto uporablja za ugotavljanje podobnosti med množicami (Lee, 2017; Nowak Da Costa, 2015). Jaccardov koeficient $J$, s katerim izračunamo podobnost med dvema podatkovnima nizoma $A$ in $B$, izračunamo, kot sledi (Jaccard, 1901):

$$
J(A, B)=\frac{|A \cap B|}{|A \cup B|} \in[0,1]
$$

Pri proučevanju podobnosti med podatkovnima nizoma se pogosto uporablja tudi Czekanowskijev koeficient $C$ (Wierzchoń in Kłopotek, 2018), ki ga med podatkovnima nizoma $A$ in $B$ izračunamo, kot sledi (Czekanowski, 1913):

$$
C(A, B)=\frac{2|A \cap B|}{|A|+|B|} \in[0,1] .
$$

Oba navedena koeficienta natančno merita ujemanje podatkov v dveh podatkovnih nizih. $V$ raziskavi take natančnosti ne potrebujemo niti ni smiselna. Zato smo ugotavljali ujemanje podatka o površini stavbe $\mathrm{v}$ občinski zbirki podatkov za odmero NUSZ in podatkov $\mathrm{v}$ registru nepremičnin tako, da smo kot ujemajoča podatka opredelili podatka, katerih vrednosti za površino se razlikujeta do $5 \%$, česar osnovna koeficienta ne štejeta za ujemanje. Zato smo morali uporabiti prilagojen Jaccardov koeficient ujemanja $J_{p}$ in prilagojen Czekanowskijev koeficient ujemanja $C_{p}$, ki smo ju za namene raziskave opredelili in izračunali po enačbi:

$$
\begin{gathered}
j_{p}=\frac{\sum_{i=1}^{n} S_{N U S Z_{-} u(i)}}{\sum_{i=1}^{n} S_{N U S Z(i)}+\sum_{i=1}^{n} S_{R E N(i)}-\sum_{i=1}^{n} S_{N U S Z u(i)}}(3) \\
C_{p}=\frac{2 \cdot \sum_{i=1}^{n} S_{N U S Z_{-} u(i)}}{\sum_{i=1}^{n} S_{N U S Z(i)}+\sum_{i=1}^{n} S_{R E N(i)}}
\end{gathered}
$$

pri čemer je:

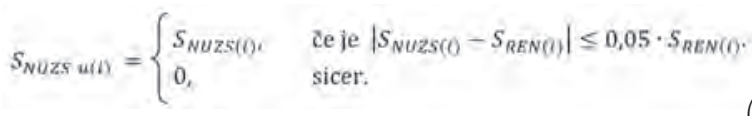

Pri tem je $S_{N U S Z(i)}$ podatek o površini stavbe $i$ v občinski zbirki podatkov za odmero NUSZ in $S_{R E N(i)}$ podatek o površini stavbe $i$ v registru nepremičnin. Obravnava ujemanja podatkov o površinah stavb in številu delov stavb med občinsko zbirko podatkov za odmero NUSZ in registrom nepremičnin je pomembna zaradi presoje kakovosti občinske zbirke podatkov za odmero NUSZ glede na referenčno zbirko podatkov. Rezultati analize ujemanja so izhodišče morebitnih ukrepov za izboljšanje kakovosti podatkov in posodobitev sistema obdavčitve nepremičnin.

$\mathrm{V}$ nadaljevanju raziskave je bila izvedena posodobitev podatkov občin za odmero NUSZ s podatki iz registra nepremičnin in zbirnega katastra gospodarske javne infrastrukture. Posodobitev podatkov občin za odmero NUSZ je bila izvedena za podatke o površini, dejanski rabi in opremljenosti s komunalno infrastrukturo. Po posodobitvi podatkov so bile vrednosti primerjanih nizov podatkov v obravnavanih zbirkah enake.

Občinske zbirke podatkov za odmero NUSZ so se s posodobitvijo spremenile. Pred posodobitvijo so vsebovale zapise za posamezni stavbni ali lastniški del, po posodobitvi podatkov vsebujejo podatek o stavbi ali nezazidanem stavbnem zemljišču kot celoti. Zaradi tega se je zmanjšalo število zapisov v občinski zbirki podatkov za odmero NUSZ. Med občinami ni enotnega pristopa za določitev davčne osnove pri določitvi višine NUSZ, tj. površine stavb. Občine v odlokih za odmero NUSZ stanovanjsko oziroma poslovno površino določajo na različne načine, npr. kot fundus stavbe, dejansko površino, tlorisno površino, neto tlorisno površino, čisto tlorisno 
Preglednica 1: Osnovni podatki o obravnavanih občinah

\begin{tabular}{lllll}
\hline Občina & $\begin{array}{l}\text { Površina občine } \\
\left(\mathrm{v} \mathrm{km}{ }^{2}\right)\end{array}$ & $\begin{array}{l}\text { Št. prebivalcev } \\
(1 . \text { polletje 2017) }\end{array}$ & $\begin{array}{l}\text { Št. hišnih številk } \\
(\text { leto 2017) }\end{array}$ & $\begin{array}{l}\text { Odmera NUSZ glede na vse prihodke } \\
\text { od obdačitve nepremičnin 2017 } \\
(\mathrm{v} \%)\end{array}$ \\
\hline Črnomelj & 339,7 & 14.365 & 4.876 & 92,3 \\
\hline Divača & 145,1 & 4.000 & 1.423 & 98,6 \\
\hline Dornava & 28,4 & 2.226 & 974 & 99,6 \\
\hline Duplek & 40,0 & 6.803 & 2.265 & 93,5 \\
\hline Mokronog - Trebelno & 73,4 & 3.045 & 1.519 & 94,9 \\
\hline Sodražica & 49,5 & 2.184 & 867 & 90,8 \\
\hline Središče ob Dravi & 32,7 & 2.019 & 757 & 96,2 \\
\hline Vuzenica & 50,1 & 2.670 & 770 & 98,6 \\
\hline Zreče & 67,0 & 6.409 & 1.897 & 93,9 \\
\hline
\end{tabular}

Vir: Statistični urad RS (2017) in Ministrstvo za finance (2018)

površino, uporabno površino idr. Pri posodobitvi občinskih zbirk podatkov za odmero NUSZ je bil uporabljen podatek iz registra nepremičnin o neto tlorisni površini dela stavbe. To je površina vseh prostorov dela stavbe ne glede na dejansko možnost uporabe prostorov. Ta površina dela stavbe, ki leži v več etažah, je vsota površin prostorov tega dela stavbe v vseh etažah (Geodetska uprava RS, 2010).

\subsection{Izbrane občine in uporabljeni podatki}

V raziskavo je bilo zajetih devet občin, ki so pristopile $\mathrm{k}$ projektu posodobitve zbirke podatkov za odmero NUSZ, in sicer Dornava, Duplek, Sodražica, Črnomelj, Divača, Vuzenica, Središče ob Dravi, Mokronog - Trebelno in Zreče. Preglednica 1 podaja osnovne podatke o obravnavanih občinah. Iz podatkov v preglednici 1 izhaja, da prihodki od NUSZ v obravnavanih občinah tvorijo izjemno velik delež vseh prihodkov od obdavčitve nepremičnin (v vseh občinah več kot $90 \%$ ). Obravnavane občine so fizičnim osebam odmerjale v povprečju višji NUSZ, kot je bilo povprečje v Sloveniji, ter v povprečju nižji NUSZ na $\mathrm{m}^{2}$ od nacionalnega povprečja za pravne osebe (razen v občini Duplek).

V raziskavi so bili uporabljeni:

- demografski podatki občin za leti 2015 in 2016 (vir: Statistični urad Republike Slovenije);

- podatki o odmeri NUSZ in davčnih prihodkih občin za leta 2015, 2016 in 2017 (vir: Ministrstvo za finance in Finančna uprava RS);

- podatki iz registra nepremičnin, meje občin, površine občin, podatki iz zbirnega katastra gospodarske javne infrastrukture (vir: Geodetska uprava RS);
- podatki in odloki o NUSZ (vir: odloki občin in zbirke podatkov občin).

\subsection{Značilnosti sistema NUSZ v obravnavanih občinah}

Vse obravnavane občine, razen Središča ob Dravi, so imele v času izvedbe raziskave sprejet odlok o NUSZ. Občina Središče ob Dravi je uporabljala odlok sosednje občine Ormož. Občine so odloke sprejemale v različnih obdobjih in nimajo enotno urejenega področja odmere NUSZ. To pomeni, da je lahko višina NUSZ za primerljiva zemljišča in stavbe v obravnavanih občinah precej različna. Vse obravnavane občine imajo v odloku opredeljeno, da odmerjajo NUSZ od zazidanega in nezazidanega stavbnega zemljišča. Izmed obravnavanih so le občine Črnomelj, Divača, Vuzenica in Zreče dejansko odmerjale NUSZ tudi od nezazidanega stavbnega zemljišča. Preglednica 2 prikazuje osnovne elemente odlokov o NUSZ v obravnavanih občinah.

Kot prikazuje preglednica 2, občine po večini upoštevajo minimalni obseg meril, opredeljenih v Zakonu o stavbnih zemljiščih (1984; 1997), tj. opremljenost stavbnega zemljišča s komunalnimi napravami in objekti, lokacijo in namembnost ter izjemne ugodnosti v zvezi s pridobivanjem dohodka v gospodarskih dejavnostih. Občine arbitrarno upoštevajo še druga merila, ki se med njimi razlikujejo. Ob tem za določitev površine stavbnega zemljišča uporabljajo različne vire podatkov (preglednica 3), pri čemer večinoma temelijio na podatkih, ki jih občinski upravi predložijo zavezanci za plačilo NUSZ. 
Preglednica 2: Število con in merila odlokov občin za določitev višine NUSZ

\begin{tabular}{|c|c|c|c|c|c|c|c|c|c|}
\hline Število con in merila odloka o NUSZ & 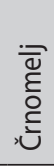 & "ָ & 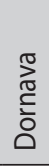 & $\frac{\frac{\text { o }}{0}}{\frac{0}{3}}$ & 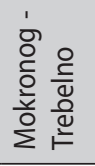 & 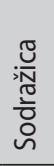 & 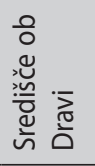 & $\begin{array}{l}\frac{\widetilde{J}}{\mathbb{N}} \\
\frac{N}{>}\end{array}$ & \\
\hline Število con & 4 & 2 & 2 & 3 & 3 & 4 & 4 & 2 & 3 \\
\hline Lokacija & - & - & - & • & - & - & - & - & - \\
\hline Opremljenost s komunalnimi napravami in objekti & & • & • & • & $\cdot$ & • & • & • & • \\
\hline Namembnost & $\cdot$ & • & • & • & $\cdot$ & & • & & • \\
\hline Izjemna ugodnost lokacije & & • & & • & $\cdot$ & & • & • & • \\
\hline Nezasedenost stavb oziroma zemljišč & $\cdot$ & • & & & $\cdot$ & & • & & \\
\hline Nenamenska uporaba & • & & & & • & & . & & \\
\hline Motnje pri uporabi & & & & $\cdot$ & • & & & • & \\
\hline Smotrnost izkoriščenosti & & & & & $\cdot$ & & & & \\
\hline $\begin{array}{l}\text { Možnost intenzivnejše rabe komunalnih in drugih objektov } \\
\text { in naprav }\end{array}$ & & & & & • & & & & \\
\hline Zapuščenost stavb oziroma zemljišč & & & & & & & • & & \\
\hline Dotrajanost stavb & & & & & & & • & & \\
\hline
\end{tabular}

Vir: Odloki občin o NUSZ, lastna analiza

Preglednica 3: Viri podatkov za določitev površine zazidanega stavbnega zemljišča za stanovanjski in poslovni namen

\begin{tabular}{ll}
\hline Občina & Vir podatkov \\
\hline Črnomelj & Register nepremičnin, kataster stavb in zemljiški kataster \\
\hline $\begin{array}{l}\text { Dornava, Duplek, Mokronog - Trebelno, } \\
\text { Sodražica }\end{array}$ & Zbirka podatkov občine \\
\hline Divača, Središče ob Dravi & Podatki uradnih evidenc in podatki, ki jih občinski upravi sporočijo zavezanci \\
\hline Vuzenica, Zreče & $\begin{array}{l}\text { Podatki neposrednega uporabnika stavbnega zemljišča, zbirka podatkov o izdanih } \\
\text { gradbenih dovoljenjih in druge uradne evidence }\end{array}$ \\
\hline
\end{tabular}

Vir: Odloki občin o NUSZ

Preglednica 4: Število zapisov v občinskih zbirkah podatkov pred posodobitvijo in po njej ter število stavb in nezazidanih stavbnih zemljišč glede na stanje v registru nepremičnin

\begin{tabular}{lllll}
\hline & \multicolumn{2}{l}{$\begin{array}{l}\text { Število vseh zapisov v občinski zbirki } \\
\text { podatkov }\end{array}$} & \multicolumn{2}{l}{$\begin{array}{l}\text { Delež stavb in nezazidanih stavbnih zemljišč } \\
\text { vseh po posodobitvi), ki }\end{array}$} \\
\hline Občina & $\begin{array}{l}\text { pred } \\
\text { posodobitvijo }\end{array}$ & $\begin{array}{l}\text { po na število } \\
\text { posodobitvi }\end{array}$ & $\begin{array}{l}\text { jih ni v občinski zbirki podatkov so v občinski zbirki podatkov in } \\
\text { in so v registru nepremičnin }\end{array}$ & \begin{tabular}{l} 
jih ni v registru nepremičnin \\
\hline Črnomelj
\end{tabular} \\
\hline Divača & 13.179 & 6.300 & $67(1,1 \%)$ & $4(0,1 \%)$ \\
\hline Dornava & 3.021 & 1.788 & $3(0,2 \%)$ & $18(1 \%)$ \\
\hline Duplek & 2.006 & 1.221 & $23(1,9 \%)$ & $10(0,8 \%)$ \\
\hline Mokronog - Trebelno & 3.862 & 2.766 & $55(2 \%)$ & $3(0,3 \%)$ \\
\hline Sodražica & 1.871 & 1.991 & $6(0,3 \%)$ & $2(0,2 \%)$ \\
\hline Središče ob Dravi & 1.669 & 1.010 & $7(0,7 \%)$ & $92(9 \%)$ \\
\hline Vuzenica & 1.694 & 1.019 & $23(2,3 \%)$ & $9(0,9 \%)$ \\
\hline Zreče & 3.815 & 2.301 & $11(1,1 \%)$ & $24(1 \%)$ \\
\hline
\end{tabular}

Vir: zbirke podatkov občin o NUSZ, register nepremičnin, lastna analiza 
V nadaljevanju so navedeni rezultati analize kakovosti občinskih zbirk podatkov po izbranih elementih kakovosti.

\subsection{Popolnost občinskih zbirk podatkov}

Popolnost je po standardu SIST EN ISO 19157:2015 primernost uporabniškega podatkovnega modela, prisotnost in odsotnost objektov, atributov in relacij ter ima lahko dva podelementa: izostanek vrednosti ali nadštevilne vrednosti. Popolnost se lahko nanaša na celovitost podatkovnega modela (modelna popolnost), popolnost atributov objektnega tipa (atributna popolnost) ali odsotnost oziroma nadštevilnost podatkovnih vrednosti v atributih prisotnih objektov (podatkovna popolnost) (Šumrada, 2015).V raziskavi smo analizirali popolnost občinskih zbirk podatkov za odmero NUSZ, ki je opredeljena z razmerjem med številom stavb in nezazidanih stavbnih zemljišč $\mathrm{v}$ zbirki podatkov in registrom nepremičnin. Tako smo ugotavljali pomanjkljive in/ali nadštevilne podatkovne vrednosti v zbirki podatkov ali podatkovnem nizu.

V vseh občinah je bila ugotovljena različna raven popolnosti zbirke podatkov. Podatki v preglednici 4 kažejo, da je v obravnavanih občinskih zbirkah podatkov za odmero NUSZ v povprečju odsoten $1,1 \%$ zapisov o stavbah in nezazidanih stavbnih zemljiščih glede na podatke registra nepremičnin. $\mathrm{V}$ obravnavanih občinah je povprečno 1,5 \% zapisov o stavbah in nezazidanih stavbnih zemljiščih, ki so v občinskih zbirkah podatkov za odmero NUSZ in jih ni v registru nepremičnin. Ugotovili smo, da se je v občinskih zbirkah podatkov za stavbo ali nezazidano stavbno zemljišče vodilo tudi več zapisov, odvisno od števila delov stavbe ali od števila lastniških deležev na nepremičnini. Analiza popolnosti atributnih podatkov, pripisanih posamezni stavbi ali nezazidanemu stavbnemu zemljišču v občinskih zbirkah podatkov za odmero NUSZ, je pokazala na pogosto odsotnost podatkov o številu točk po posameznih merilih odloka. V številnih primerih je bilo pripisano le skupno število točk.

\subsection{Tematska natančnost občinskih zbirk podatkov za odmero NUSZ}

Tematska natančnost podaja zanesljivost razvrstitve vrednosti, ki so pripisane osnovnim elementom podatkov kot atributi in ima lahko, glede na določila standarda SIST EN ISO 19157:2015, tri podelemente: pravilnost razvrstitve podatkov, kvantitativno pravilnost vrednosti opisnih atributov in kvantitativno točnost. V raziskavi smo se osredotočili na primerjavo točnosti podatka o površini stavbe in nezazidanega stavbnega zemljišča v občinskih zbirkah podatkov za odmero NUSZ glede na podatek $\mathrm{v}$ registru nepremičnin. Ob vzpostavitvi občinskih zbirk podatkov v 90. letih prejšnjega stoletja je bil $\mathrm{v}$ večini primerov $\mathrm{v}$ veljavi pojem koristne površine ( $\mathrm{s}$ korekcijskimi faktorji za različne prostore), zato je v registru nepremičnin uporabljena neto tlorisna površina praviloma večja od koristne površine.

Podatki v preglednici 5 kažejo, da se podatki o številu delov stavb med občinskimi zbirkami podatkov za odmero NUSZ in registrom nepremičnin razmeroma dobro ujemajo (povprečna vrednost Jaccardovega koeficienta $J=0,87$ ). Med obravnavanimi občinami so manjše razlike. Nekoliko drugačne rezultate dobimo pri analizi površine stavb in nezazidanega stavbnega zemljišča. Če upoštevamo predpostavljeno mejo za prilagojena Jaccardov in Czekanowskijev koeficient 0,33 (vrednosti pod to mejo označujejo večje odstopanje podatkov), potem je največje odstopanje podatkov o površini stavb in nezazidanega stavbnega zemljišča med občinsko zbirko podatkov in registrom nepremičnin v občini Mokronog - Trebelno $\left(J_{p}=0,15\right.$ in $\left.C_{p}=0,27\right)$ in občini Dornava $\left(J_{p}=0,31\right.$ in $\left.C_{p}=0,47\right)$. V drugih obravnavanih občinah se $J_{p}$ giblje med 0,41 in 0,73 , $C_{p}$ pa med 0,58 in 0,85 . Temu ustrezen je tudi rezultat glede povprečnega odstopanja in razlik v površinah za več kot $50 \%$. Poprečno odstopanje površin stavb in nezazidanega stavbnega zemljišča med občinsko zbirko za odmero NUSZ in registrom nepremičnin znaša od $18 \mathrm{~m}^{2} \mathrm{v}$ občini Sodražica do $511 \mathrm{~m}^{2} \mathrm{v}$ občini Mokronog -Trebelno. Delež stavb in nezazidanih stavbnih zemljišč v občinski zbirki podatkov za odmero NUSZ, katerih površina za več kot $50 \%$ odstopa od površine v registru nepremičnin, se giblje med 1,01 \% v občini Duplek do 9,83\% v občini Dornava.

\subsection{Logična usklajenost podatkov iz občinskih zbirk podatkov}

Logična usklajenost se nanaša na pojmovne (semantika), formatne (zapis), domenske (obseg vrednosti) in oblikovne protislovnosti v zbirki podatkov. Logična usklajenost podaja skladnost pojmovnih pravil podatkovnega modela in strukture podatkov v podatkovnem nizu (sestave razredov, atributov in relacij med njimi) (Šumrada, 2015). Pri analizi logične usklajenosti podatkov občinskih zbirk podatkov za odmero NUSZ je ugotovljeno, da je bilo v občinskih zbirkah podatkov za stavbo ali nezazidano stavbno zemljišče več zapisov. Zaznanih je bilo veliko primerov neusklajenosti podatkov o rabi stavbe ali dela stavbe, nekateri zapisi o stavbi ali nezazidanem stavbnem zemljišču so bili v registru nepremičnin in jih ni bilo v občinski zbirki podatkov ali nasprotno. Poleg tega je bila v več primerih ugotovljena odsotnost podatka o hišni številki. Kot že omenjeno, površina dela stavbe $v$ občinski zbirki podatkov za odmero NUSZ ni enaka površini dela stavbe $\mathrm{v}$ registru nepremičnin. Glede na to, da občine v odlokih o NUSZ upoštevajo različna merila, je težko izvesti primerjalno analizo. 
Preglednica 5: Ujemanje podatkov o številu delov stavb ter površini stavb in nezazidanega stavbnega zemljišča med občinsko zbirko podatkov za odmero NUSZ in registrom nepremičnin

\begin{tabular}{llllll} 
& \multicolumn{2}{l}{$\begin{array}{l}\text { Število delov } \\
\text { stavbe }\end{array}$} & \multicolumn{2}{c}{ Površina stavb in nezazidanega stavbnega zemljišča } \\
\hline Občina & $\begin{array}{l}\text { Jaccardov } \\
\text { koeficient } J\end{array}$ & $\begin{array}{l}\text { Prilagojen Jaccardov } \\
\text { koeficient } J_{p}\end{array}$ & $\begin{array}{l}\text { Prilagojen } \\
\text { Czekanowskijev } \\
\text { koeficient } C_{p}\end{array}$ & $\begin{array}{l}\text { Povprečno } \\
\text { odstopanje } \\
\left.\mathrm{m}^{2}\right)\end{array}$ & $\begin{array}{l}\text { Razlika površine več } \\
\text { kot } 50 \%{ }^{(b)}(\mathrm{v} \%)\end{array}$ \\
\hline Črnomelj & 0,86 & 0,51 & 0,68 & 91 & 2,46 \\
\hline Divača & 0,83 & 0,50 & 0,66 & 117 & 5,31 \\
\hline Dornava & 0,80 & 0,31 & 0,47 & 59 & 9,83 \\
\hline Duplek & 0,93 & 0,73 & 0,85 & 18 & 1,01 \\
\hline Mokronog - Trebelno & 0,84 & 0,15 & 0,27 & 511 & 8,49 \\
\hline Sodražica & 0,92 & 0,65 & 0,79 & 28 & 2,57 \\
\hline Sredičče ob Dravi & 0,83 & 0,55 & 0,71 & 36 & 4,91 \\
\hline Vuzenica & 0,92 & 0,41 & 0,58 & 138 & 1,88 \\
\hline Zreče & 0,94 & 0,54 & 0,71 & 140 & 1,35 \\
\hline
\end{tabular}

Vir: lastni izračun

Opomba: (a) Povprečno odstopanje površin stavb in nezazidanega stavbnega zemljišča med občinsko zbirko podatkov in registrom nepremičnin. (b) Delež stavb in nezazidanih stavbnih zemljišč v občinski zbirki podatkov za odmero NUSZ, katerih površina za več kot $50 \%$ odstopa od površine $v$ registru nepremičnin.

Preglednica 6: Podatki o odmeri NUSZ pred posodobitvijo občinskih zbirk podatkov za odmero NUSZ in po njej

\begin{tabular}{|c|c|c|c|c|c|c|c|c|c|c|c|}
\hline \multirow[b]{3}{*}{ Občina } & \multicolumn{5}{|c|}{$\begin{array}{c}\text { Podatki o NUSZ } \\
\text { pred posodobitvijo }\end{array}$} & \multicolumn{5}{|c|}{$\begin{array}{l}\text { Podatki o NUSZ } \\
\text { po posodobitvi }\end{array}$} & \multirow[b]{3}{*}{$\begin{array}{l}\text { Indeks odmere } \\
\text { pred/po }\end{array}$} \\
\hline & \multicolumn{2}{|c|}{ Pravne osebe } & \multicolumn{2}{|c|}{ Fizične osebe } & \multirow[b]{2}{*}{$\begin{array}{l}\text { Odmera } \\
\text { skupaj } \\
\text { (v EUR) } \\
\end{array}$} & \multicolumn{2}{|c|}{ Pravne osebe } & \multicolumn{2}{|c|}{ Fizične osebe } & \multirow[b]{2}{*}{$\begin{array}{l}\text { Odmera } \\
\text { skupaj } \\
\text { (v EUR) }\end{array}$} & \\
\hline & $\begin{array}{c}\text { Št. } \\
\text { odločb }\end{array}$ & $\begin{array}{l}\text { Odmera } \\
\text { (v EUR) }\end{array}$ & $\begin{array}{c}\text { Št. } \\
\text { odločb }\end{array}$ & $\begin{array}{l}\text { Odmera } \\
\text { (v EUR) }\end{array}$ & & $\begin{array}{c}\text { Št. } \\
\text { odločb }\end{array}$ & $\begin{array}{l}\text { Odmera } \\
\text { (v EUR) }\end{array}$ & $\begin{array}{c}\text { Št. } \\
\text { odločb }\end{array}$ & $\begin{array}{l}\text { Odmera } \\
\text { (v EUR) }\end{array}$ & & \\
\hline Črnomelj & 202 & 191.764 & 4.794 & 196.476 & 388.239 & 210 & 278.696 & 5.743 & 327.739 & 606.435 & 156 \\
\hline Divača & 47 & 137.011 & 1.220 & 60.664 & 197.675 & 77 & 164.465 & 1.755 & 96.315 & 260.780 & 132 \\
\hline Dornava & 12 & 5.668 & 801 & 57.475 & 63.143 & 17 & 19.732 & 1.073 & 86.290 & 106.022 & 168 \\
\hline Duplek & 28 & 27.534 & 1.940 & 136.914 & 164.448 & 40 & 33.346 & 2.620 & 230.471 & 263.817 & 160 \\
\hline $\begin{array}{l}\text { Mokronog - } \\
\text { Trebelno }\end{array}$ & 29 & 30.420 & 1.291 & 70.268 & 100.688 & 30 & 33.596 & 1.402 & 82.049 & 115.645 & 115 \\
\hline Sodražica & 27 & 7.928 & 702 & 25.272 & 33.200 & 27 & 10.956 & 931 & 45.089 & 56.045 & 169 \\
\hline $\begin{array}{l}\text { Središče ob } \\
\text { Dravi }\end{array}$ & 17 & 27.030 & 824 & 104.410 & 131.440 & 26 & 39.386 & 913 & 115.139 & 154.525 & 118 \\
\hline Vuzenica & 24 & 131.546 & 579 & 25.924 & 157.470 & 34 & 126.595 & 1.143 & 50.532 & 177.128 & 112 \\
\hline Zreče & 138 & 323.663 & 2.155 & 164.030 & 487.693 & 164 & 332.487 & 2.332 & 195.407 & 527.893 & 108 \\
\hline
\end{tabular}

Vir: Ministrstvo za finance, 2017; lastni izračun

\subsection{Učinki posodobitve občinskih zbirk podatkov na odmero NUSZ}

Osrednji namen raziskave je bil ugotoviti, ali posodobitev občinske zbirke podatkov za odmero NUSZ o zazidanih in nezazidanih stavbnih zemljiščih $\mathrm{v}$ izbranih občinah $s$ podatki iz registra nepremičnin pozitivno vpliva na višino odmere NUSZ. Oziroma ali se je z izboljšanjem kakovosti podatkov zvišala odmera NUSZ v obravnavanih občinah. Rezultati v preglednici 6 kažejo, da je uporaba podatkov iz registra nepremičnin pozitivno vplivala na višino odmere NUSZ v vseh obravnavanih občinah.

Število zavezancev za plačilo NUSZ, tako pravnih kot fizičnih oseb, se je po posodobitvi občinskih zbirk podatkov v vseh občinah povečalo v povprečju za približno $30 \%$. V obravnava- 
nih občinah je odmera NUSZ po posodobitvi občinskih zbirk podatkov v povprečju višja za $38 \%$ glede na odmero NUSZ pred posodobitvijo. V občini Duplek se je odmera NUSZ po posodobitvi podatkov povečala za $60 \%$, v občini Dornava za $68 \%$, v občini Sodražica pa za kar $69 \%$. Večje ko je povprečno odstopanje površine stavbe in nezazidanega stavbnega zemljišča med občinsko zbirko podatkov za odmero NUSZ in registrom nepremičnin, manj se zviša odmera NUSZ po posodobitvi podatkov. $V$ vseh občinah je po izvedeni posodobitvi podatkov zaznano razmeroma visoko zvišanje odmere NUSZ glede na vse davčne prihodke občine (povprečno povečanje znaša $d_{\text {prih }}=51,3 \%$ ).

\section{Sklep}

V raziskavi smo v izbranih občinah analizirali kakovost zbirk podatkov, ki jih občine v Sloveniji uporabljajo za upravljanje sistema NUSZ. Rezultati kažejo, da obravnavane občine za upravljanje sistema NUSZ vodijo lastne zbirke podatkov. Te zbirke so bile večinoma vzpostavljene v 90 . letih prejšnjega stoletja na podlagi popisa nepremičnin oziroma na podlagi podatkov, ki so jih sporočili zavezanci za plačilo NUSZ. Občinske zbirke podatkov za odmero NUSZ so vzdrževane predvsem na zahtevo zavezancev za plačilo NUSZ, ob spremembah lastništva, na podlagi zahtev davčnega organa ali sodišč. Obravnavane občine so pred izvedeno posodobitvijo zbirk podatkov te večinoma vodile v preglednicah, brez podpore GIS-tehnologije in kartografskih prikazov stanja nepremičnin v prostoru. Med obravnavanimi ima le občina Črnomelj v odloku o NUSZ navedeno, da se za določitev površine zazidanega stavbnega zemljišča in dejanske rabe uporabljajo podatki iz registra nepremičnin, katastra stavb in zemljiškega katastra. Zaradi odsotnosti enotnega identifikatorja stavbe in dela stavbe je bil v raziskavi zaznan tudi problem povezovanja občinskih zbirk podatkov za odmero NUSZ z registrom nepremičnin.

V okviru raziskave je bilo za obravnavane občine ugotovljeno, da je kakovost občinskih zbirk podatkov za odmero NUSZ raznovrstna po vseh obravnavanih elementih kakovosti: popolnosti, logične usklajenosti in tematske natančnosti. Ugotovitve raziskave kažejo, da je v občinskih zbirkah podatkov za odmero NUSZ zajeta večina stavb, delov stavb in nezazidanih stavbnih zemljiščc, ki so zajeti v registru nepremičnin in so predmet odmere NUSZ, s čimer hipotezo H1 zavrnemo. Nadštevnih stavb, delov stavb in stavbnih zemljǐ̌č (so zajeti v občinski zbirki podatkov za odmero NUSZ in jih $\mathrm{v}$ registru nepremičnin ni) je bilo razmeroma malo, razen v občini Središče ob Dravi (9 \% vseh zapisov). Ugotovili smo pogosto odsotnost atributnih podatkov, predvsem šsevila točk po posameznem merilu iz odloka o NUSZ. Z Jaccardovim koeficientom $J_{p}$ smo ugotovili razmeroma visoko raven ujemanja števila delov stavbe $\mathrm{v}$ občinskih zbirkah podatkov in v registru nepremičnin. Potrdili smo uporabnost prilagojenega Jaccardovega koeficienta $J_{p}$ in prilagojenega Czekanowskijevega koeficienta $C_{p}$. Ujemanje podatkov ob upoštevanju vsaj 5 -odstotnega odstopanja vrednosti je sprejemljiva mera, glede na to, da so podatki o površini nepremičnin pridobljeni z različnimi metodami v različnih obdobjih. Sprejemljiva je tudi z vidika racionalnosti, ker se postopki posodobitve ne izvedejo, če so odstopanja manjša od $5 \% . Z J_{p}$ in $C_{p}$ smo potrdili razmeroma nizko raven ujemanja podatkov o površinah stavb in nezazidanega stavbnega zemljišča med občinskimi zbirkami podatkov za odmero NUSZ in registrom nepremičnin. $S$ tem smo potrdili hipotezo H2. Izrazitejša je tudi logična neusklajenost podatkov med občinskimi zbirkami podatkov za odmero NUSZ in registrom nepremičnin. Potrdili smo hipotezo H3, da posodobitev podatkovnih nizov v občinskih zbirkah podatkov s podatki registra nepremičnin pomembno vpliva na povečanje števila zavezancev in višino odmere NUSZ ( $\mathrm{v}$ obravnavanih občinah povprečno za $38 \%$, v nekaterih od njih celo za več kot $60 \%$ ). Uporabnost navedene metodologije se potrjuje tudi s primerjavo rezultatov. Rezultati raziskave, izvedene z navedeno metodo, so glede na vrsto in obseg neskladnosti med občinskimi zbirkami podatkov za NUSZ in registrom nepremičnin ter glede na odstotek povišanja odmere NUSZ po izvedenem procesu izboljšanja kakovosti podatkov zelo podobni rezultatom raziskav Gerčerja (2017), Grilca (2017) in Ziherla (2017).

Neustrezna kakovost prostorskih podatkov, ki jih občine uporabljajo za odmero NUSZ, ima lahko večrazsežne posledice. Neposredno vpliva na povečanje števila pritožb zoper odločbe o odmeri NUSZ. Poveča se verjetnost kršitve načel sodobnega davčnega sistema in ustavnih načel, predvsem zakonitosti in enakosti pred zakonom. Zbirke podatkov občin, ki jih občine vodijo za odmero NUSZ, se stalno spreminjajo. To terja ustrezne pristope upravljanja, temelječe na sodobni GIS-tehnologiji. Ob referenčnih zbirkah podatkov so na voljo tudi številni drugi podatkovni viri (npr. Google Map, Open Street Map in druge prostovoljno zbrane zbirke prostorskih podatkov), $s$ katerimi je mogoče primerjati kakovost izbranih podatkovnih nizov v občinskih zbirkah podatkov za odmero NUSZ. Navedena metoda je uporabna predvsem, kadar je $\mathrm{v}$ med seboj primerjanih zbirkah podatkov vzpostavljen enoten identifikator nepremičnine.

Tovrstno raziskavo bi bilo smiselno izvesti v vseh občinah v Sloveniji, pri čemer bi s posodobitvijo zbirk podatkov za odmero NUSZ prispevali k izboljšanju kakovosti podatkov o stavbah in nezazidanih stavbnih zemljiščih. Urejena in kakovostna zbirka podatkov za odmero NUSZ bi omogočala pravičnejšo, učinkovitejšo in racionalnejšo obdavčitev nepremičnin. To posledično vpliva tudi na raven družbene sprejemljivosti obdavčitve nepremičnine, stabilnost davčnih prihodkov in znižuje raven 
izogibanja plačevanja NUSZ. Kakovostna zbirka podatkov za odmero NUSZ bi bila uporabna tudi na drugih področjih, npr. za urejanje prostora, prostorsko načrtovanje, upravljanje nepremičnin idr. Izziv za izvedbo tovrstne raziskave $\mathrm{v}$ vseh občinah je povezan $\mathrm{z}$ neenotnim podatkovnim modelom in zahtevnim procesom pridobivanja in urejanja podatkov.

Slovenija se zaveda pomena doseganja ravnovesja med povečanjem prihodkov in gospodarsko rastjo z izboljšanjem kakovosti obdavčenja. Pri tem želi izboljšati strukturo posameznih vrst davkov, med drugim z razširitvijo davčnih osnov, ter izboljšati izpolnjevanje davčnih obveznosti in okrepiti davčno upravo. V okviru tega načrtuje nadaljnje reforme obdavčitve nepremičnin, saj davki na nepremičnine, kot navajajo številni avtorji (Johansson idr., 2008; Heady idr., 2009; Arnold idr., 2011), najmanj ovirajo gospodarsko rast. Glede na aktivne gospodarske in zakonodajne spremembe na lokalni in državni ravni so lahko rezultati raziskave v podporo odločitvam na obravnavanem področju. Na izsledke raziskave se je mogoče nasloniti tudi pri pripravi sprememb sistema obdavčitve nepremičnin v Sloveniji. Pri pripravi novega sistema obdavčitve nepremičnin je treba posebno pozornost nameniti kakovosti in medopravilnosti uradnih zbirk podatkov o nepremičninah. Zato predlagamo izvajanje redne, neodvisne presoje kakovosti podatkov v skladu s standardiziranimi metodami in izvajanje programov ozaveščanja lastnikov nepremičnin o stanju podatkov in o pomenu kakovosti podatkov o njihovih nepremičninah. $\mathrm{K}$ izboljšanju kakovosti uradnih zbirk podatkov lahko prispevata tudi spletna storitev vpogleda v podatke o nepremičninah in možnost predlaganja sprememb podatkov z ustreznimi, uporabniku prilagojenimi kartografskimi prikazi podatkov.

\section{Simon Starček, Ig, Slovenija}

E-naslov: simon.starcek@gmail.com

Maruška Šubic Kovač, Univerza v Ljubljani, Fakulteta za gradbeništvo in geodezijo, Ljubljana, Slovenija

E-naslov: maruska.subic-kovac@fgg.uni-lj.si

\section{Zahvala}

Zahvaljujemo se Mihi Požauku in podjetju Realis, d. o. o., za podporo pri izvedbi raziskave in uporabo podatkov občin za odmero NUSZ.

\section{Viri in literatura}

Aamir, M., in Bhusry, M. (2015): Recommendation system: state of the art approach. International Journal of Computer Applications, 120(12), str. 25-32. DOI: 10.5120/21281-4200

Albatineh, A. N., in Niewiadomska-Bugaj, M. (2011): Correcting Jaccard and other similarity indices for chance agreement in cluster analysis. Advances in Data Analysis and Classification, 5(3), str. 179-200. DOI: 10.1007/s11634-011-0090-y
Ariza-López, F. J., in Mozas-Calvache, A. T. (2012): Comparison of four line-based positional assessment methods by means of synthetic data. Geolnformatica, 16(2), str. 221-243. DOI: 10.1007/s10707-011-0130-y

Arnold, J. M., Brys, B., Heady, C., Johansson, A., Schwellnus, C., in Vartia, L. (2011): Tax policy for economic recovery and growth. The Economic Journal, 121, str. 59-80. DOI: 10.1111/j.1468-0297.2010.02415.x

Ažman, I. (2011): Kakovost podatkov in direktiva INSPIRE. Geodetski vestnik 55(2), str. 193-204.

DOI: 10.15292/geodetski-vestnik.2011.02.193-204

Barańska, A. (2004): Criteria of database quality appraisement and choice stochastic models in prediction of real estate market value. Prispevek je bil predstavljen na konferenci z naslovom FIG Working Week, ki je potekala od 22. do 27. maja 2004 v Atenah v Grčiji. Tipkopis.

Barvika, S., Rausis, A., in Berzina, I. (2013): Opportunities for the development of the Latvian property tax administration system through improvements in the property registration system and the implementation of European Union requirements for geospatial information. V: Schrenk, M., Popovich, V. V., Zeile, P., in Elisei, P. (ur.) Proceedings of 18th international conference on urban planning, regional development and information society, str. 671-682. Schwechat, Competence Center of Urban and Regional Planning.

Bohak, R. (2016): Prostorski podatki v podporo odločanju in razvoju. Zbornik prispevkov, 44. geodetski dan. Laško, Zveza geodetov Slovenije.

Caeiro, C., Rocha, G., Januário, P., Martins, P., Faustino, S., in Jacinto, T. (2016): Portuguese cadastre. Actual state, case studies, projects, data infrastructure. Prispevek je bil predstavljen na konferenci z naslovom FIG Commission 7 Annual Meeting \& Geoconference, ki je potekala od 24. do 28. oktobra 2016 v Coimbri na Portugalskem. Tipkopis.

Çağdaş, V. (2013): An application domain extension to CityGML for immovable property taxation: A Turkish case study. International Journal of Applied Earth Observation and Geoinformation, 21, str. 545-555. DOI: 10.1016/j.jag.2012.07.013

Cerovski, T. (2010): Avtomatsko ocenjevanje kakovosti prostorskih podatkov. Diplomska naloga. Ljubljana, Univerza v Ljubljani, Fakulteta za računalništvo in informatiko.

Czekanowski, J. (1913): Zarys metod statystcznych w zastosowaniu do antropologii. Travaux de la Société des Sciences de Varsovie. III. Classe des sciences mathématiques et naturelles, 5. Warsaw, Société des Sciences de Varsovie. DOI: 10.2307/2266986

Čeh, M., Lisec, A., Ferlan, M., in Šumrada, R. (2011). Geodetsko podprta prenova grafičnega dela zemljiškega katastra $=$ The renovation of the land cadastre's graphical part based on surveying principles. Geodetski vestnik, 55(2), str. 257-268.

DOI: 10.15292/geodetski-vestnik.2011.02.257-268

Droj, L., in Droj, G. (2010): Spatial decision support system for property taxation modelling. V: Proceedings of 15th International Business Information Management Association Conference on Global Business Transformation through Innovation and Knowledge Management: An Academic Perspective, str. 1746-1758.

Ferlan, M. (2005): Geodetske evidence. Univerza v Ljubljani, Fakulteta za gradbeništvo in geodezijo, Oddelek za geodezijo.

Ferlan, M., Šumrada, R., Čeh, M., in Lisec, A. (2011): Načini vzpostavitve digitalnih katastrskih načrtov $v$ primerljivih državah $=$ Approaches to the establishment of digital cadastral maps in comparable countries. Geodetski vestnik, 55(2), str. 235-256.

DOI: 10.15292/geodetski-vestnik.2011.02.235-256

Finančna uprava RS (2014): Odmera nadomestila za uporabo stavbnega zemljišča za leto 2014 (št. 4224-1106/2014-6 (01-630-00) z dne 25. 4. 2014). Ljubljana, Finančna uprava RS. 
Geodetski inštitut Slovenije (2003): Ocena natančnosti podatkov zemljiškega katastra. Poročilo o izvajanju projekta. Geodetski vestnik, 47(3),str. 337-342.

Geodetski inštitut Slovenije (2009): Opredelitev natančnosti v katastru stavb. Končno poročilo. Ljubljana.

Geodetska uprava RS (2010): Obveščanje lastnikov nepremičnin o poskusnem izračunu vrednosti nepremičnin. Ljubljana.

Geodetska uprava RS (2013): Metodologija vodenja in vzdrževanja Registra nepremičnin. Ljubljana.

Gerčer, S. (2017): iObčina - pomoč zagotavljanja boljše izvedbe NUSZ in bodočega davka na nepremičnine. Prispevek na konferenci. Ljubljana, Skupnost občin Slovenije. Tipkopis.

Goodchild, M. F., in Hunter, G. J. (1997): A simple positional accuracy measure for linear features. International Journal of Geographical Information Science, 11(3), str. 299-306. DOI: 10.1080/136588197242419

Grilc, M. (2017): NUSZ - predstavitev projekta prenove evidence v Mestni občini Kranj. Prispevek na konferenci. Ljubljana, Skupnost občin Slovenije. Tipkopis.

Grote, M., Borst, R., in McCluskey, W. (2015): Slovenia. The 2013 property tax act: evaluation of its design and the employed mass valuation system. Washington, International Monetary Fund. DOI: 10.5089/9781498352062.002

Hashemi, P., in Abbaspour, R. A. (2015): Assessment of logical consistency in OpenStreetMap based on the spatial similarity concept. V: Arsanjani, J. J. idr. (ur.) OpenStreetMap in GIScience. Lecture Notes in Geoinformation and Cartography, str. 19-36. Cham, Springer. DOI: 10.1007/978-3-319-14280-7_2

Hast, I. (2014): Quality assessment of spatial data: Positional uncertainties of the national shoreline data of Sweden. Diplomska naloga. Gävle, University of Gävle, Faculty of engineering and sustainable development.

Heady, C., Johansson, Å., Arnold, J., Brys, B., in Vartia, L. (2009): Tax Policy for Economic Recovery and Growth. V: School of Economics Discussion Papers, 9(25), str. 2-22. Kent, University of Kent, School of Economics.

Ivánová, I. (2007): Modelling of the data quality in the spatial domain. Slovak journal of Civil Engineering, 2, str. 28-34.

Jaccard, P. (1901): Étude comparative de la distribution florale dans une portion des Alpes et du Jura'. Bulletin Societe' Vandoise des sciences naturelles, 37, str. 547-579.

Jankovič Grobelšek, L., in Gajšek, M. (2014): Izkušnje in izzivi na področju zemljiške politike: na primeru Mestne občine Ljubljana. Urbani izziv, strokovna izdaja, str. 63-69.

Johansson, A., Heady, C., Arnold, J., Brys, B., in Vartia, L. (2008): Tax and Economic Growth. OECD Economics Department Working Papers, No. 620. Paris, OECD Publishing.

Kobetič, L. (2014): Podatki o nepremičninah v javnih evidencah kot podlaga za njihovo obdavčitev. Evidentiranje in obdavčitev stavbnih zemljišč. Podjetje in delo, 6-7, str. 1189-1208.

Kokkonen, A. (2006): The use of register data for mass valuation and taxation in Finland. Helsinki, National Land Survey of Finland.

Lee, S. (2017): Improving Jaccard index using genetic algorithms for collaborative filtering. V: Tan, Y., Takagi, H. in Shi, Y. (ur.) International Conference on Swarm Intelligence ICSI 2017: Advances in Swarm Intelligence, Lecture Notes in Computer Science 10385: str. 378-385. Cham, Springer. DOI: 10.1007/978-3-319-61824-1_41
Lisec, A., Ferlan, M., Čeh, M., Trobec, B., in Drobne, S. (2015): Analiza kakovosti Registra nepremičnin in predlog sistema za zagotavljanje kakovosti podatkov. Končno poročilo, marec 2015. Ljubljana, Univerza v Ljubljani, Fakulteta za gradbeništvo in geodezijo.

Liu, H., Hu, Z., Mian, A., Tian, H., in Zhu, X. (2014): A new user similarity model to improve the accuracy of collaborative filtering. Knowledge-Based Systems, 56, str. 156-166. DOI: 10.1016/j.knosys.2013.11.006

Maggio, F. (2012): The Italian cadastre and the real estate taxation. Prispevek je bil predstavljen na konferenci, z naslovom FIG working week, Knowing to manage the territory, protect the environment, evaluate the cultural heritage, ki je potekala od 6. do 10. maja v Rimu. Tipkopis.

Maher, I., Gosar, L., Mezek, S., in Plazar Mlakar, M. (2005): Prostorski informacijski sistem v programu CAMP Slovenija: podatki in metapodatki. Urbani izziv, 16(2), str. 94-99. DOI: 10.5379/urbani-izziv-2005-16-02-013

Mangioni, V. (2012): Land value taxation. Meeting the principles of transparency in good tax design. Prispevek je bil predstavljen na konferenci, z naslovom FIG working week, Knowing to manage the territory, protect the environment, evaluate the cultural heritage, ki je potekala od 6 . do 10. maja v Rimu. Tipkopis.

Mantey, S., in Tagoe, N. D. (2012): Geo-Property tax information system A case study of the Tarkwa Nsuaem Municipality, Ghana. Prispevek je bil predstavljen na konferenci, $z$ naslovom FIG working week, Knowing to manage the territory, protect the environment, evaluate the cultural heritage, ki je potekala od 6. do 10. maja v Rimu. Tipkopis.

McKay, S. (2003): Quantifying quality: Can quantitative data („metrics") explain the 2001 RAE ratings for social policy and administration? Social Policy \& Administration, 37(5), str. 444-467. DOI: 10.1111/1467-9515.00351

Ministrstvo za finance (2017): Podatki o odmeri nadomestila za uporabo stavbnega zemljišča. Ljubljana.

Ministrstvo za okolje in prostor, Ministrstvo za finance, Ministrstvo za javno upravo (2016): Sistemska priporočila za izboljšanje sistema nadomestila za uporabo stavbnega zemljišča. Ljubljana.

Mitrović, D. (2015): »Razumevanje« ocenjevanja vrednosti nepremičnin $v$ Sloveniji $=$ »Understanding " of real property valuation in Slovenia. Geodetski vestnik, 59(3), str. 593-608.

Mivšek, E., in Radovan, B. (2017): Izboljšanje prostorskih podatkov za dosego boljšega upravljanja s prostorom in več sredstev za razvoj. Prispevek na konferenci. Ljubljana, Ministrstvo za okolje in prostor, Geodetski inštitut Slovenije.

Morrison, J. L. (1995): Spatial data quality. V: Guptill, S. C. in Morrison, J. L. (ur.) Elements of spatial data quality. A volume in International Cartographic Association, str. 1-12. Oxford, Elsevier. DOI: 10.1016/b978-0-08-042432-3.50008-2

Nowak Da Costa, J. (2015): Preučevanje popolnosti podatkov na podlagi primerjalne analize med podatki VGI in uradnimi podatkovnimi nizi o stavbah = Novel tool for examination of data completeness based on a comparative study of VGI data and official building datasets. Geodetski vestnik, 60 (3), str. 495-508.

DOI: 10.15292/geodetski-vestnik.2016.03.495-508

Petrovič, D. (2006): Ocena kakovosti državne topografske karte v merilu $1: 50000=$ Quality evaluation of the national topographic map $1: 50$ 000. Geodetski vestnik, 50(2), str. 187-200.

Pipino, L. L., Lee, Y. W., in Wang, R. Y. (2002): Data quality assessment. Communications of the ACM, 45(4), str. 211-218. 
Podobnikar, T. (2001): Digitalni model reliefa iz geodetskih podatkov različne kakovosti. Doktorska disertacija. Ljubljana, Univerza v Ljubljani, Fakulteta za gradbeništvo in geodezijo.

Požun, T. (2015): Analiza podatkovnega modela in podatkov registra nepremičnin. Magistrsko delo. Ljubljana, Univerza v Ljubljani, Fakulteta za gradbeništvo in geodezijo.

Režek, J., Berk, S., in Grilc, M. (2015): Lahko slabi prostorski podatki "spremenijo tok vode«? Urbani izziv, strokovna izdaja, str. 38-46.

Robbins, G. (2014): Prospects for spatial knowledge tools in municipal budget systems with a focus on property tax issues. Chance2Sustain; Policy Brief, 18(Oct.), str. 1-7.

Romesburg, H. C. (2004): Cluster analysis for researchers. Morrisville, Lulu Press.

SIST EN ISO 19157:2015. Geografske informacije - kakovost podatkov.

Slack, E., in Bird, R. M. (2014): The political economy of property tax reform. Working papers on fiscal federalism, No. 18. Paris, OECD Publishing. DOI: 10.1787/5jz5pzvzv6r7-en

Smodiš, M. (2011): Zaključevanje uvedbe množičnega vrednotenja nepremičnin. Geodetski vestnik, 55(2), str. 334-348.

DOI: 10.15292/geodetski-vestnik.2011.02.334-348

Starček, S. (2017): Uporabnost zbirk prostorskih podatkov in njihove kartografske upodobitve za potrebe obdavčitve nepremičnin. Doktorska disertacija. Ljubljana, Univerza v Ljubljani, Fakulteta za gradbeništvo in geodezijo.

Statistični urad RS (2017): Podatki o številu prebivalcev občin, površini občin in hišnih številkah v občinah za leto 2017. Ljubljana.

Šumrada, R. (2005): Strukture podatkov in prostorske analize. Ljubljana, Univerza v Ljubljani, Fakulteta za gradbeništvo in geodezijo.

Šumrada, R. (2015): Kakovost prostorskih podatkov - kratek pregled. Ljubljana, Univerza v Ljubljani, Fakulteta za gradbeništvo in geodezijo.

Tomić, H. (2010): Analiza geoprostornih podataka za potrebe vrednovanja nekretnina u urbanim područjima. Doktorska disertacija. Zagreb, Sveučičište u Zagrebu, Geodetski fakultet.

Triglav, J. (2012): Tretji klic k razmisleku in ducat dobrih idej. Geodetski vestnik, 56(3), str. 579-594.

Triglav Čekada, M., Mesner, N., in Barborič, B. (2016): Lasersko skeniranje kot vir podatkov o vseh stavbah v Sloveniji. V: Ciglič, R., Geršič, M., Perko, D. in Zorn, M. (ur.): GIS v Sloveniji. Digitalni podatki, str. 167-177. Ljubljana, Geografski inštitut Antona Melika ZRC SAZU.

DOI: $10.3986 /$ gv88207

Združeni narodi (2014): Survey on land administration systems. New York, Ekonomska komisija Združenih narodov za Evropo.

Urankar, S. (2016): Problematika, s katero se davčni organ srečuje pri odmeri nadomestila za uporabo stavbnega zemljišča in rešitve pri uvedbi davka na nepremičnine. Magistrsko delo. Ljubljana, Univerza v Ljubljani, Pravna fakulteta.

Ustavno sodišče RS (2014): Odločba št. U-I-313/13-86. Ljubljana.

Van der Molen, P. (2002): The use of the Cadastre among the Members States. Property rights, land registration and Cadastre in the European Union. Seminar 1. The use of the Cadastre. 1st Congress on cadastre in the European union, str. 227-230. Granada, Permanent Committee on Cadastre in the European Union. DOI: 10.1007/978-3-319-51216-7 20

Veregin, H. (1999): Data quality parameters. V: Longley, P. A., Goodchild, M. F., Maguire, D. J., in Rhind, D. W. (ur.): Geographical Information Systems, str. 177-189. New York, John Wiley and Sons.
Vlada RS (2013): Predlog zakona o davku na nepremičnine. EVA: 20131611-0071, št. 00712-48/2013/22, z dne 17. 10. 2013. Ljubljana.

Wierzchoń, S. T., in Kłopotek, M. A. (2018): Cluster Analysis. V: Wierzchoń, S. T. in Kłopotek, M. A. (ur.): Modern algorithms of cluster analysis. Studies in Big Data 34, str. 9-66. Cham, Springer. DOI: 10.1007/978-3-319-69308-8_2

Zakon o davku na nepremičnine. Uradni list Republike Slovenije, št. 101/13, 22/14 - odl. US.

Zakon o graditvi objektov. Uradni list Republike Slovenije, št. 102/04, s spremembami.

Zakon o stavbnih zemljiščih. Uradni list Socialistične republike Slovenije, št. 18/84, s spremembami.

Zakon o stavbnih zemljiščih. Uradni list Republike Slovenije, št. 44/97, s spremembami.

Zakrajšek, F. J. (1999): Cilji implementacije geoinformacijske podpore planiranju in urejanju prostora na lokalni ravni v okviru projekta ONIX. Urbani izziv, 10(1), str. 63-65. DOI: 10.5379/urbani-izziv-1999-10-01-009

Zavodnik Lamovšek, A., Kerpan, N., in Foški, M. (2012): Spremembe namenske rabe prostora glede na razvoj slovenske prostorske zakonodaje v obdobju 1984-2007. Urbani izziv, 2012, strokovna izdaja, str. 5-17.

Ziherl, J. (2017): Izkušnje mestne občine Kranj pri izboljšavi podatkov za odmero NUSZ. Prispevek je bil predstavljen na konferenci z naslovom Priprave na NUSZ v letu 2017 za kakovostno izvedbo NUSZ v letu 2018/2019, ki je potekala 14. junija 2017 v Medvodah. Tipkopis.

Xia, J. (2012): Metrics to measure open geospatial data quality in Issues in Science and Technology Librarianship. Science and Technology Librarianship, 68.

Yomralioglu, T., Nisanci, R., in Yildirim, V. (2007): An Implementation of Nominal Asset Based Land Readjustment. Prispevek je bil predstavljen na konferenci z naslovom FIG Working Week, ki je potekala od 13. do 17. maja 2007 v Hongkongu. Tipkopis. 